\title{
POST-OPERATIVE PAIN AFTER SINGLE-VISIT ENDODONTIC TREATMENT USING DIFFERENT ROOT CANAL IRRIGATION ACTIVATING TECHNIQUES
}

\author{
Ahmed Ibrahim Salim*, Abeer Mostafa Darrag** and Walaa Mohamed Ghoneim***
}

\begin{abstract}
Aim: To clinically evaluate the effect of different irrigation activating techniques (needle irrigation, passive ultrasonic irrigation (PUI) and EndoVac) on post-operative pain after single-visit endodontic treatment.

Materials and methods: Thirty patients aged between 16 and 40 years requiring endodontic therapy of asymptomatic vital/non vital maxillary central or canine teeth were selected. In all cases, root canal treatment was done is single-visit in which root canals were prepared using nickeltitanium ProTaper Universal rotary system in crown down manner up to master apical file size F4 or F5 according to the initial apical canal size. Irrigation was done using $2.5 \% \mathrm{NaOCl}$. Patients were randomly assigned into three groups according to the final irrigation activation method, group 1 (control group) needle irrigation, group 2 PUI and group 3 EndoVac system. Obturation was done using cold lateral compaction technique. Post-operative pain was assessed after 6, 12, 24, 48 hours, one week and two weeks respectively. Post-operative pain evaluation was done using Visual Analogue Scale (VAS).
\end{abstract}

Results: EndoVac group showed the least post-operative pain values while needle irrigation group showed the highest values. This was statistically significant at 6 and 48 hours time intervals. PUI group showed lower pain values than needle group and this was significant at 48 hours time interval. In all groups the intensity of post-operative pain decreased over time.

Conclusion: EndoVac system and PUI reduce post-operative pain after single-visit endodontic treatment than needle irrigation in the first 48 hours.

KEYWORDS: EndoVac, Needle irrigation, Passive ultrasonic irrigation, Post-operative pain, Single-visit.

\footnotetext{
* Instructor, Endodontics, Faculty of Dentistry, Tanta University

** Professor, Endodontic Department, Faculty of Dentistry, Tanta University

*** Assistant Professor, Endodontic Department, Faculty of Dentistry, Tanta University
} 


\section{INTRODUCTION}

The key to successful endodontic treatment is complete debridement of the root canal system of necrotic or infected pulp tissues, microorganisms, and complete sealing of the root canal space. It is clinically characterized by absence of symptoms, swelling and sinus tract and radiographically by evidence of normal periodontal ligament space, or gradual decrease in the size of periapical radiolucency in case of periapical lesion during follow up periods.

Post-operative pain is defined as the unpleasant sensation of any degree of pain that occurs after root canal treatment (RCT). It occurs due to an acute inflammatory response in the periradicular tissues after being exposed to mechanical, chemical, and microbial irritation. Extrusion of dentin chips, pulp tissue, microorganisms, and/or irrigants into the periradicular tissues during root canal preparation and irrigation procedures could cause postoperative pain, swelling, and persistent inflammation ${ }^{(1)}$.

Pain perception is mainly a subjective and variable experience that depends on many psychological and physical factors. The visual analog scale (VAS) is usually used as a measure of pain intensity in clinical researches due to its simplicity. The VAS intensity rating consisted of a 100 -mm length line with two end points as no pain and worst pain ${ }^{(2)}$.

Nowadays single visit endodontic treatment is advocated by many because it is considered that there is less chances of root canal contamination during procedure due to less number of appointments required for completion of procedure, less chances of loss of temporary seal which leads to coronal leakage and hence failure of root canal treatment, reduced procedural costs and minimal patient anxiety.

Irrigation process is important for bacteria and debris removal from root canal system. Sodium hypochlorite $(\mathrm{NaOCl})$ is widely used due to its pronounced antimicrobial activity and its ability to dissolve organic matter. However, its extrusion into the periapical tissues through the apical constriction is one of the risks associated with its use due to strong cell toxicity leading to severe immediate pain, profuse intracanal bleeding, progressive swelling, and sometimes ecchymosis ${ }^{(3)}$.

Irrigant is usually delivered into the root canal using a side-vented or notched needle. Conventional manual irrigation with a syringe and needle is widely used but it has been proven to be incapable of delivering irrigant into areas with difficult access such as the apical and isthmus regions.Thus, different irrigation agitation techniques have been developed to improve irrigation efficacy within the root canal system. These include agitation with hand files, gutta-percha cones, sonic , passive ultrasonic, apical negative pressure irrigation system and photon-initiated photo acoustic streaming ${ }^{(4)}$.

Passive ultrasonic irrigation (PUI) was introduced to improve the effectiveness of canal disinfection by agitating an irrigation solution previously placed inside the canal using ultrasonic tip placed $2 \mathrm{~mm}$ short of the WL with moving the tip passively in an up-and-down motion not to bind with the root canal walls ${ }^{(5)}$.

The EndoVac apical negative pressure irrigation system was shown to safely irrigate root canals using negative pressure in the apical terminus to move the irrigation solution through negative pressure gradients ${ }^{(6)}$.

With the new era of different methods for activation of irrigating solutions inside root canal, this study was conducted to evaluate post-operative pain after single-visit RCT.

\section{MATERIALS AND METHODS}

\section{Study design}

This study was conducted as a randomized clinical study. 


\section{Study setting}

This study was conducted in outpatients who presented to clinic of Endodontic Department, Faculty of Dentistry, Tanta University.

\section{Sample size}

Thirty patients aged between 16 and 40 years requiring endodontic treatment of maxillary central or canine teeth were selected for this study.

\section{Patient selection}

\section{Inclusion criteria}

- Asymptomatic vital/non vital teeth requiring root canal treatment.

- Teeth having sound periodontal apparatus.

- Teeth with no pus or inflammatory exudates draining through the canal.

- Teeth with sinus tract.

- Teeth selected as abutments.

- Patients not on analgesics or sedative medication prior to root canal therapy ${ }^{(7)}$.

\section{Exclusion criteria}

- Patients with any systemic diseases

- Immunocompromised or pregnant patients.

- Retreatment cases

- Teeth with calcified canals.

- Patients with acute apical periodontitis, acute apical abscess and weeping canals ${ }^{(7,8)}$.

\footnotetext{
* New Life Radiology sr.I,Grugliasco TO, ITALY.

** Dr. SuniPlus, Suni Medical Imaging Inc., CA, USA

*** ARTINIBSA $40 \mathrm{mg} / 0,01 \mathrm{mg} / \mathrm{ml}$,insiba, Spain

***** Midwest Dental, Texas, USA.

***** Komet; Brasseler, Lemgo, Germany.

******* NSK, Tokyo, Japan.

******** MANI Inc, Utsunomiya, Japan

\# J. Morita, Tokyo, Japan
}

\section{Ethical considerations}

Approval for this research was obtained from Research Ethics Committee, Faculty of Dentistry, Tanta University. The purpose of the present study was explained to the patients and informed consents were obtained according to the guidelines on human research adopted by the Research Ethics Committee, Faculty of Dentistry, Tanta University.

\section{Group assignment}

Thirty patients were randomly divided into three equal groups $(n=10)$ according to the irrigation activating technique:

Group1: Side-vented needle (control group).

Group2: Passive ultrasonic activation.

Group3: EndoVac system.

\section{Treatment protocol}

Case history was taken and thorough clinical examination was made. A pre-operative digital radiograph* $^{*}$ using Dr.Suni* ${ }^{* *}$ software was taken to check the canal, periodontal and periapical tissues $^{(7)}$. Local anesthetic ${ }^{* * *}$ was administered and treated tooth was isolated using rubber dam ${ }^{* * * * *}$. The access cavity was prepared using long shank rose head bur size $2^{* * * * *}$ and Endo $\mathrm{Z}$ bur** attached to high speed contra angle headpiece ${ }^{* * * * * * *}$. Pulp tissue was extirpated using barbed broach ${ }^{* * * * * * *}$ and working length (WL) was determined with the aid of apex locator ${ }^{* * * * * * * * *}$ and then confirmed by digital radiograph using, \#20 or \#25 initial apical file according to each canal size. 
Root canals were prepared in all cases using nickel-titanium ProTaper Universal * rotary system consisting of shaping files (SX, S1, S2) and finishing files (F1, F2, F3, F4, F5) in crown down manner according to manufacture instructions at $300 \mathrm{rpm}$ using 16:1 reduction handpiece ${ }^{* *}$ powered by torque limited electric motor ${ }^{\dagger \dagger t}$ up to master apical file size F4 (40/.05) or F5 (50/0.04) according to the initial apical canal size ${ }^{(9)}$.

Biomechanical preparations of all groups were done using $2.5 \% \mathrm{NaOCl}$ solution as a root canal irrigant. Ten $\mathrm{mL}$ were used during access cavity preparation and initial coronal instrumentation and five $\mathrm{mL}$ were used after every use of a rotary instrument ${ }^{(10)}$.

Irrigation in group 1 was done throughout instrumentation using 27-gauge side-vented needle ${ }^{* * * *}$ inserted inside canal with no bending $2 \mathrm{~mm}$ short of working length and in up-and-down motion to improve irrigant flow rate ${ }^{(10,11)}$. The final activation of irrigation was done in six cycles using 10 $\mathrm{mL}$ of $2.5 \% \mathrm{NaOCl}^{(4)}$ in four cycles and $5 \mathrm{ml}$ of $17 \%$ EDTA in two cycles ${ }^{(12)}$. Each cycle was done as follows, the root canal was filled with $2.5 \mathrm{~mL}$ of $2.5 \% \mathrm{NaOCl}$ delivered by disposable syringe and 27 -gauge side-vented needle, inserted up to $2 \mathrm{~mm}$ short of the working length and in up-and-down motion for 30 seconds and then left in place for 1 minute. First two, and last two cycles were done with $\mathrm{NaOCl}$ and the in-between two cycles were done with $\operatorname{EDTA}^{(13,14)}$.

In group 2, Irrigation was done as in group 1 throughout instrumentation but final irrigation activation was done as follows: irrigants were continuously delivered into the canal while being activated simultaneously using a smooth ultrasonic file ${ }^{* * * *}(20 / 0.02)$ coupled to the file-holding adapter of the ultrasonic system handpiece ${ }^{t+1 \dagger}$. The ultrasonic file was inserted passively without engaging the dentinal walls at $2 \mathrm{~mm}$ shorter than the WL with short, up-down movements and activated with a defined power setting of 6 according to manufacturer's instructions ${ }^{(15)}$. The procedure was repeated in six sequences of 30 seconds ${ }^{(13)}$.

First, the root canal was filled with $2.5 \mathrm{~mL}$ of $2.5 \% \mathrm{NaOCl}$ delivered by disposable syringe and 27-gauge side-vented needle then ultrasonically activated for 30 seconds. This was followed by another cycle of $\mathrm{NaOCl}$ followed by two cycles of EDTA and finally two cycles of $\mathrm{NaOCl}^{(13)}$.

In group 3, EndoVac system ${ }^{* * * * *}$ was used following the manufacturer's recommendations. During mechanical preparation, the EndoVac master delivery tip (MDT) was inserted above the access opening to constantly deliver and evacuate $2.5 \% \mathrm{NaOCl}$ solution ${ }^{(11,14)}$.

After reaching the working length with the master apical file, macroirrigation of each canal with $2.5 \mathrm{~mL}, 2.5 \% \mathrm{NaOCl}$ solution was done over a 30 -second period. This was performed by using the EndoVac MDT delivering the irrigant while the macrocannula attached to handpiece was constantly moved up and down in the canal from a point where it started to bind to a point just below the orifice sucking the irrigant. The canal space was then left full of irrigant for 60 seconds ${ }^{(11,14)}$.

Three cycles of microirrigation were followed, during which the pulp chamber was kept full of irrigant while the microcannula attached to finger piece set was placed at the working length for 6

\footnotetext{
* Dentsply Maillefer, Ballaigues, Switzerland.

** Endo E Class ,Marathon, Daegu, Korea.

*** Ultra- dent, South Jordan, UT.

**** Acteon Group, Merignac, France.

***** Discus Dental, Culver City,GA.

****** Dentsply DeTrev GmbH, Konstanz Germany.

******** SPSS Inc. Chicago, USA.
} 
seconds then positioned $2 \mathrm{~mm}$ from the working length for 6 seconds and then moved back to the working length for 6 seconds. This up-down motion continued for 30 seconds. Then, the microcannula was withdrawn from the canal in the presence of sufficient irrigant in the pulp chamber to ensure that the canal remained totally filled with irrigant and that no air was drawn into the canal space and left undisturbed for 60 seconds. The first cycle was done using $2.5 \mathrm{~mL}$ of $2.5 \% \mathrm{NaOCl}$ solution. The second cycle was done for 1 min using $5 \mathrm{ml}$ of $17 \%$ EDTA. The third cycle was done using $5 \mathrm{~mL}$ of $2.5 \% \mathrm{NaOCl}$ for one minute ${ }^{(11,14)}$.

During the treatment, patients were not aware of the used irrigation device. After complete root canal preparation and irrigation; the canals were finally irrigated with $3 \mathrm{~mL}$ saline then dried using paper point ${ }^{* * *}$. The canals were obturated after preparation with $\mathrm{AH}$ Plus* sealer(Fig.IV-12) with gutta percha*** (Fig.IV13) using cold lateral condensation technique then post-operative radiographic evaluation was done to ensure ideal root canal obturation ${ }^{(16)}$.

\section{Postoperative pain evaluation}

It was done using VAS. Patients can place a mark anywhere on the horizontal VAS form having values between 0 and 100 and scoring was done according to Jensen et $\mathrm{al}^{(17)}$.

- Score 0: No pain (0 to $4 \mathrm{~mm}$ ) the treated tooth felt normal. Patients don't have any pain.

- Score 1: Mild pain (5 to $44 \mathrm{~mm}$ ) recognizable, but not discomforting pain which required no analgesics.

- Score 2: Moderate pain (45 to 74) discomforting, but bearable pain (analgesics, if used, are effective in relieving the pain)

- Score 3: Severe pain (75 to $100 \mathrm{~mm}$ ) difficult to bear (analgesics have little or no effect in relieving the pain)

\footnotetext{
* Dentsply DeTrev GmbH, Konstanz Germany.

** SPSS Inc. Chicago, USA.
}

Patients' first record was taken preoperatively for pain levels in the presence of the clinician to ensure that they understood the instructions regarding the pain. Then, further six readings were recorded for postoperative periods of $6,12,24,48$ hours, one week and two weeks respectively. Each patient was given a prescription for $600 \mathrm{mg}$ of Ibuprofen for pain relief only if needed under supervision of endodontist ${ }^{(8)}$.

\section{Statistical analysis}

The data were collected, tabulated and statistically analyzed using SPSS statistic program (version 21) ${ }^{*}$. Kruskal-Wallis test was used to compare pain incidence between groups and Mann-Whitney U Test was used to make pairwise comparisons between groups if significant differences were found. $\mathrm{P}$-value less than or equal to 0.05 was considered statistically significant.

\section{RESULTS}

Statistical significant differences among the three groups at 6 hours time interval and 48 hours time interval were found. So Mann-Whitney pairwise comparisons were done and showed statistical significant differences between group 1 versus group 3 at 6 hours time interval. At 48 hours time interval, there were statistical significant differences between group 1 versus group 2 and group 3 (Table 1)

Comparison of post-operative pain among the three tested groups regardless time interval revealed statistical significant differences between all groups ( $\mathrm{P}$-value $<0.001)$ with highest pain levels were recorded in group 1 and lowest pain levels were recoded in group 3. Mann-Whitney pairwise comparisons showed statistical significant differences between group 1 versus group 2 (P-value 0.023 ), group 1 versus group 3(P-value $<0.001$ ) and group 2 versus group 3(P-value 0.029$)$. 
TABLE (1): Number and percentage of cases recording different scores of post-operative pain in the three tested groups at each time interval and their statistical analysis

\begin{tabular}{|c|c|c|c|c|c|c|c|c|c|c|c|c|}
\hline \multirow{3}{*}{\multicolumn{2}{|c|}{$\begin{array}{c}\text { Time intervals } \\
\text { scores }\end{array}$}} & \multicolumn{6}{|c|}{ Groups } & \multirow{2}{*}{\multicolumn{2}{|c|}{$\begin{array}{c}\text { Kruskal- } \\
\text { Wallis Test }\end{array}$}} & \multirow{2}{*}{\multicolumn{3}{|c|}{ Mann-Whitney Test }} \\
\hline & & \multicolumn{2}{|c|}{ Group 1} & \multicolumn{2}{|c|}{ Group 2} & \multicolumn{2}{|c|}{ Group 3} & & & & & \\
\hline & & $\mathbf{N}$ & $\%$ & $\mathbf{N}$ & $\%$ & $\mathbf{N}$ & $\%$ & $\mathrm{X}^{2}$ & P-value & $1 \& 2$ & $1 \& 3$ & $2 \& 3$ \\
\hline \multirow{5}{*}{ לֶ. } & Score 0 & 2 & 20.00 & 3 & 30.00 & 6 & 60.00 & \multirow{5}{*}{6.448} & \multirow{5}{*}{$0.040^{*}$} & \multirow{5}{*}{0.339} & \multirow{5}{*}{$0.016^{*}$} & \multirow{5}{*}{0.084} \\
\hline & Score 1 & 3 & 30.00 & 4 & 40.00 & 4 & 40.00 & & & & & \\
\hline & Score 2 & 4 & 40.00 & 3 & 30.00 & 0 & 0.00 & & & & & \\
\hline & Score 3 & 1 & 10.00 & 0 & 0.00 & 0 & 0.00 & & & & & \\
\hline & Median & \multicolumn{2}{|c|}{1.5} & \multicolumn{2}{|r|}{1} & \multicolumn{2}{|r|}{0} & & & & & \\
\hline \multirow{4}{*}{ 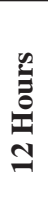 } & Score 0 & 2 & 20.00 & 3 & 30.00 & 6 & 60.00 & \multirow{4}{*}{5.677} & \multirow{4}{*}{0.059} & & & \\
\hline & Score 1 & 4 & 40.00 & 5 & 50.00 & 4 & 40.00 & & & & & \\
\hline & Score 2 & 4 & 40.00 & 2 & 20.00 & 0 & 0.00 & & & & & \\
\hline & Median & \multicolumn{2}{|r|}{1} & \multicolumn{2}{|r|}{1} & \multicolumn{2}{|r|}{0} & & & & & \\
\hline \multirow{4}{*}{ 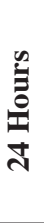 } & Score 0 & 2 & 20.00 & 5 & 50.00 & 7 & 70.00 & \multirow{4}{*}{5.541} & \multirow{4}{*}{0.063} & & & \\
\hline & Score 1 & 7 & 70.00 & 5 & 50.00 & 3 & 30.00 & & & & & \\
\hline & Score 2 & 1 & 10.00 & 0 & 0.00 & 0 & 0.00 & & & & & \\
\hline & Median & \multicolumn{2}{|r|}{1} & \multicolumn{2}{|c|}{0.5} & \multicolumn{2}{|r|}{0} & & & & & \\
\hline \multirow{3}{*}{ 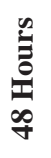 } & Score 0 & 2 & 20.00 & 7 & 70.00 & 8 & 80.00 & \multirow{3}{*}{8.136} & \multirow{3}{*}{$0.017^{*}$} & & & \\
\hline & Score 1 & 8 & 80.00 & 3 & 30.00 & 2 & 20.00 & & & $0.028 *$ & $0.009 *$ & 0.615 \\
\hline & Median & & 1 & & 0 & & 0 & & & & & \\
\hline & Score 0 & 7 & 70.00 & 9 & 90.00 & 10 & 100.00 & & & & & \\
\hline$\sum^{\circ}$ & Score 1 & 3 & 30.00 & 1 & 10.00 & 0 & 0.00 & 3.904 & 0.142 & & & \\
\hline- & Median & & 0 & & 0 & & 0 & & & & & \\
\hline$\ddot{ّ}$ & Score 0 & 10 & 100.00 & 10 & 100.00 & 10 & 100.00 & 000 & 1000 & & & \\
\hline$\sum_{1}^{2}$ & Median & & 0 & & 0 & & 0 & 0.000 & 1.000 & & & \\
\hline
\end{tabular}

In Comparing recorded post-operative pain at six time intervals in each group, it was found that a high statistical significant difference was found among the 6 time intervals in group 1 (P-value $<0.001)$ and group 2 (P-value $<0.001)$ while there was no statistical significant difference among the 6 time intervals in group 3 .

In group 1, Wilcoxon Signed Ranks Test was done and showed significant differences between 6 hours time interval versus all the other time intervals except 12 hours time interval. Additionally, there was no statistical significant difference between 12 hours and 24 hours time intervals, 24 hours and 48 hours time intervals nor between one week and two weeks time intervals.

In group 2, Wilcoxon Signed Ranks Test was done and showed significant differences between 6 hours time interval versus all the other time intervals except 12 hours time interval. While no statistical significant difference was recorded between 24 hours and 48 hours time intervals, 48 hours and one week time intervals, 48 hours and two weeks time intervals nor between one week and two weeks time intervals. 


\section{DISCUSSION}

The success of endodontic therapy is not only defined by the efficacy of cleaning, shaping, and obturation but also by the degree of post-operative discomfort ${ }^{(18)}$. Therefore, the incidence of pain in root canal treatment has been a matter of concern even with the inception of advanced endodontic instruments ${ }^{(18)}$. Factors affecting the incidence and severity of pain are still not clear because of limitations of pain evaluating researches ${ }^{(10)}$. No single factor is affecting post-operative pain and it may be due to mechanical, chemical and/or microbial injury to the pulp or periradicular tissues ${ }^{(19)}$. Irrigating solutions or medications can evoke pain by irritating the periradicular tissues ${ }^{(9)}$. So, this study was done to evaluate post-operative pain after using different irrigation activation techniques in single visit endodontic treatment.

The used irrigant solution throughout mechanical instrumentation in this study was $\mathrm{NaOCl}$ due to its wide spectrum antibacterial effect and high dissolution capacity. A medium concentration $(2.5 \%)$ was used since in lower concentrations, the dissolution capacity and antibiofilm effect are decreased and in higher concentrations, toxicity and negative effect on dentin structure is increased. It was followed by EDTA to remove the inorganic part of smear layer, thereby exposing the dentinal tubule openings for the next irrigant or sealer ${ }^{(3)}$.

The control group in this study was syringe irrigation as it is the most widely used because of its simplicity and irrigant volume control ${ }^{(20)}$. Side-vented needles were used as it creates more pressure on the walls of the root canal and improve the hydrodynamic activation of an irrigant, while avoiding the inadvertent extrusion of the irrigant into periapical tissues ${ }^{(21)}$.

PUI is more effective than conventional syringe irrigation regarding removal of pulp tissue and dentin debris ${ }^{(22)}$ and many researchers have proven that the use of PUI significantly reduces the number of bacteria ${ }^{23-25)}$. EndoVac system was also shown to have better microbial elemination than the conventional syringe irrigation delivery system ${ }^{(26)}$. PUI and EndoVac systems were compared to side-vented needle concerning post-operative pain in the present study as little studies are found regarding this point.

Evaluation of a single variable as the cause of postoperative pain is very difficult mission as pain is affected by many other factors which are impossible to eliminate in a clinical scenario. However, welldesigned single variable analysis provides valuable information regarding the impact of that variable on the occurrence of pain ${ }^{(27)}$. So, strict inclusion criteria were adopted in this study to eliminate the effect of other preoperative factors.

Asymptomatic teeth were selected because preoperative pain has great impact on occurrence of postoperative pain. Teeth with apical periodontitis, acute apical abscess or retreatment cases were not included, and a highly aseptic protocol was maintained to prevent bacterial contamination ${ }^{(28)}$.

Only single canaled teeth were incorporated in this study to decrease the risk of missed or complicated root canal anatomy and to make sure that each canal would be irrigated with the same amount of irrigant solution. Instrumentation and obturation were done in single visit to remove the effect of intra-canal medication as another possible factor for post-operative pain. Furthermore, only patients having no analgesic medication recently were included in this study so that no drug interaction could interfere with post-operative pain after endodontic treatment ${ }^{(9)}$.

In the present study, electronic root canal length measurement device was used to determine WL and then it was radiologically confirmed. This ensures that preparation would be confined within the root canal system, thereby preventing the over instrumentation that is considered to be one of the causes of post-operative pain ${ }^{(2)}$. 
During syringe irrigation and to avoid forcing irrigants into the periapical tissue some precautions were done as not binding the needle, not reaching WL with the needle, and using a gentle pressure of irrigation ${ }^{(29)}$. Needle tip was kept $2 \mathrm{~mm}$ short from the apex as a safety measure which is within $1.5-3 \mathrm{~mm}$ from $\mathrm{WL}^{(30)}$.

In this study, PUI intermittent flush technique was used to have control on the amount of irrigant flowing through the apical region because both the depth of needle penetration and the amount of irrigant administered were known which is not possible with continuous ultrasonic irrigation ${ }^{(31)}$. One of the characteristics of the ultrasonic activated instruments is the cleaning promoted by acoustic flow and cavitation, which requires an enlargement of the root canal for an adequate performance, and for this reason as well as for the anatomic possibility of the teeth used in this study the root canals were instrumented until ProTaper F4 and F5 ${ }^{(32)}$.

In PUI activation, \#20 endosonic file was used to be less likely to contact the canal walls and prevent a dampening effect on the canal wall and inserted $2 \mathrm{~mm}$ shorter of the WL as the contact between an ultrasonic tip and the dentinal wall may result in diminished amplitude and the reduction of irrigant's streaming velocity. Shorter passive irrigation makes it easier to keep the file in the center of the canal and therefore prevents it from touching the walls and creating aberrant forms. Therefore, in this study PUI activation was done for 30 seconds $^{(33)}$.

For the EndoVac group, the macrocannula was inserted short of binding, and the microcannula was inserted to WL as recommended by the manufacturer $^{(34)}$. The amount of irrigant delivered between files and during final irrigation was controlled, six cycles of irrigation activation were done in needle irrigation and PUI groups ${ }^{(33)}$ and four cycles in EndoVac group ${ }^{(34)}$ with the same amount of irrigant, to evaluate the sole role of irrigation activation techniques ${ }^{(35)}$.
Post-operative pain is highly subjective and is affected by several factors. So, different scales and methods have been used to assess postoperative pain. The current study used the VAS $(100 \mathrm{~mm})$ scale ranging from 0 to 10 to measure the intensity of postoperative pain. This scale has been widely used in previous studies evaluating post-operative pain after RCT due to its simplicity, validity, and

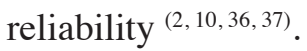

In general, the pain levels experienced by the patients in our study were very low, with only 1 of 30 total reports exceeding moderate pain. No patient reported complications like swelling or paresthesia. This is in agreement with Gondim et al. ${ }^{(9)}$ regarding pain levels.

Post-operative pain recorded with highest values after 6 hours of treatment, which started to decrease in the following periods until it almost disappeared after one week. This is in agreement with several studies evaluating the duration of postoperative pain after RCT ${ }^{(12,38-40)}$. This could be due to the possible irritation of the periapical area during endodontic treatment that caused the local inflammatory response that decreased after healing of the periapical area ${ }^{(41)}$.

Pain values were lower in Endovac group compared to conventional needle group and it was significant after 6 hours and 48 hours time interval. These finding is in agreement with Gondim et al. ${ }^{(9)}$ and Topçuoğlu et al. ${ }^{(12)}$. The increased pain levels with conventional needle-syringe irrigation can due to positive pressure of conventional irrigation that extrudes greater weight of debris apically. Further, the inability to completely remove vital/ necrotic pulpal remnants and microbes as it can't reach full working length and that could contribute to the reported post-operative pain ${ }^{(42)}$. Additionally, It could be viewed that sodium hypochlorite accident can occur with the greatest potential during needle irrigation with manual agitation ${ }^{(43)}$. 
It was shown that using EndoVac system significantly results in less apical extrusion of irrigant. So, chemical irritation of the periapical tissues leading to post-operative pain may not be likely ${ }^{(44-46)}$. Romualdo et al. ${ }^{(47)}$ reported that using apical negative pressure during irrigation prevents the apical extrusion of the irrigant compared with positive pressure.

Compared to PUI, Syringe irrigation group showed higher post-operative pain levels and that was significant at 48 hours time interval. Laboratory studies comparing Ultrasonic irrigation with syringe irrigation have reported Ultrasonic irrigation to be more effective in debris removal from the apical third ${ }^{(48)}$ and narrow isthmuses ${ }^{(49)}$. In addition, PUI group extruded less debris than the conventional syringe irrigation group ${ }^{(50,51)}$. This is an agreement with Middha et $\mathrm{al}^{(10)}$ but the difference was significant on the first day only.

This was also supported by Tang et al. ${ }^{(52)}$ who compared post-operative pain levels after 24 hours and one week of single-visit treatment. The results demonstrated that the pain levels at 24 hours and one week after the procedure were significantly lower in ultrasonic groups than conventional syringe needle group.

This was in disagreement with Topçuoğlu et al..$^{(2)}$ and Gündoğar et al. ${ }^{(38)}$ who found no significant difference between side-vented needle group and passive ultrasonic irrigation group. This may be due to presence of pre-operative pain in all cases in these studies. Additionally, Other studies ${ }^{(20,53,54)}$ showed no statistical significant difference between Syringe irrigation and PUI regarding irrigant extrusion.

Moreover, Gupta et al. ${ }^{(55)}$ found that the maximum extrusion of debris as well as irrigant was observed in PUI group. This might be because in PUI the tip was inserted only $1 \mathrm{~mm}$ short of WL while the instrument tip was $2 \mathrm{~mm}$ short of WL in other activation groups,. Also, Hizarci et al. ${ }^{(56)}$ stated that the amount of apical debris extrusion was statistically higher in PUI than syringe needle irrigation.

\section{CONCLUSION}

Within the limitations of this study, it was concluded that:

- None of the tested irrigation activation techniques completely prevented the occurrence of post-operative pain.

- Intensity of post-operative pain was decreased over time in all groups.

- Using EndoVac system (negative pressure irrigation) and PUI had better results in reducing post-operative pain than using needle irrigation in the first 48 hours.

- Using negative pressure irrigation system reduces the occurrence of post-operative pain than positive pressure irrigation systems regardless time intervals.

\section{REFERENCE}

1. Gündoğar M, Sezgin GP, Kaplan SS, Özyürek H, Uslu G, Özyürek T. Postoperative pain after different irrigation activation techniques: a randomized, clinical trial. Odontology. 2021;109(2):385-92.

2. Topçuoğlu HS, Topçuoğlu G, Arslan H. The Effect of Different Irrigation Agitation Techniques on postoperative pain in mandibular molar teeth with symptomatic irreversible pulpitis: a randomized clinical trial. J Endod. 2018;44(10):1451-6.

3. Bukhari S, Babaeer A. Irrigation in Endodontics: a Review. Curr. Oral Health Rep. 2019;6(4):367-76.

4. Gu L-s, Kim JR, Ling J, Choi KK, Pashley DH, Tay FR. Review of contemporary irrigant agitation techniques and devices. J Endod. 2009;35(6):791-804.

5. Munoz HR, Camacho-Cuadra K. In vivo efficacy of three different endodontic irrigation systems for irrigant delivery to working length of mesial canals of mandibular molars. J Endod. 2012;38(4):445-8.

6. Mitchell RP, Baumgartner JC, Sedgley CM. Apical extrusion of sodium hypochlorite using different root canal irrigation systems. J Endod. 2011;37(12):1677-81.

7. Bhagwat $S$, Mehta D. Incidence of post-operative pain following single visit endodontics in vital and non-vital teeth: An in vivo study. Contemp Clin Dent. 2013;4(3):295-302. 
8. PAtil AA, JoShi SB, Bhagwat S, PAtil SA. Incidence of postoperative pain after single visit and two visit root canal therapy: a randomized controlled trial. JCDR. 2016;10(5):9-12.

9. Gondim Jr E, Setzer FC, Dos Carmo CB, Kim S. Postoperative pain after the application of two different irrigation devices in a prospective randomized clinical trial. J Endod. 2010;36(8):1295-301.

10. Middha M, Sangwan P, Tewari S, Duhan J. Effect of continuous ultrasonic irrigation on postoperative pain in mandibular molars with nonvital pulps: a randomized clinical trial. Int Endod J. 2017;50(6):522-30.

11. Suman S, Verma P, Prakash-Tikku A, Bains R, KumarShakya V. A comparative evaluation of smear layer removal using apical negative pressure (EndoVac), Sonic irrigation (EndoActivator) and Er: YAG laser-an in vitro SEM study. J.clin .exp. dent. 2017;9(8): 81-87.

12. Topçuoğlu HS, Topçuoğlu G, Arslan H. The Effect of Apical Positive and Negative Pressure Irrigation Methods on Postoperative Pain in Mandibular Molar Teeth with Symptomatic Irreversible Pulpitis: A Randomized Clinical Trial. J Endod. 2018;44(8):1210-5.

13. Nakamura VC, Pinheiro ET, Prado LC, Silveira A, Carvalho A, Mayer MPA, et al. Effect of ultrasonic activation on the reduction of bacteria and endotoxins in root canals: a randomized clinical trial. Int Endod J. 2018;51:12-22.

14. Miller TA, Baumgartner JC. Comparison of the antimicrobial efficacy of irrigation using the EndoVac to endodontic needle delivery. J Endod. 2010;36(3):509-11.

15. Aksel H, Küçükkaya Eren S, Puralı N, Serper A, Azim AA. Efficacy of different irrigant protocols and application systems on sealer penetration using a stepwise CLSM analysis. Microsc. Res. Tech. 2017:1-5.

16. Wong AW-Y, Zhang S, Li SK-Y, Zhu X, Zhang C, Chu $\mathrm{C}$-H. Incidence of post-obturation pain after single-visit versus multiple-visit non-surgical endodontic treatments. BMC oral health. 2015;15(1):96.

17. Jensen MP, Chen C, Brugger AM. Interpretation of visual ana$\log$ scale ratings and change scores: a reanalysis of two clinical trials of postoperative pain. J.Pain. 2003; 4(7):407-14.

18. Saha SG, Gupta RK, Bhardwaj A, Misuriya A, Saha MK, Nirwan AS. Comparison of the incidence of postoperative pain after using a continuous rotary system, a reciprocating system, and a Self-Adjusting File system in single-visit endodontics: A prospective randomized clinical trial. J conserv dent. 2018;21(3):333-38.

19. Sathorn C, Parashos P, Messer H. The prevalence of postoperative pain and flare up in single and multiple visit endodontic treatment: a systematic review. Int Endod J. 2008;41(2):91-9.

20. Sarıyılmaz E, Keskin C. Apical Extrusion of Debris and Irrigant Using XP-Endo Finisher, EndoActivator, Passive Ultrasonic Irrigation or Syringe Irrigation. Meandros Med. Dental J. 2018;19(2):127-31.

21. Sedgley C, Nagel A, Hall D, Applegate B. Influence of irrigant needle depth in removing bioluminescent bacteria inoculated into instrumented root canals using real time imaging in vitro. Int Endod J. 2005;38(2):97-104.

22. Mozo S, Llena C, Forner L. Review of ultrasonic irrigation in endodontics: increasing action of irrigating solutions. Med Oral Patol Oral Cir Bucal. 2012;17(3):512-16.

23. Al-Jadaa A, Paqué F, Attin T, Zehnder M. Acoustic hypochlorite activation in simulated curved canals. J Endod. 2009;35(10):1408-11.

24. Plotino G, Pameijer CH, Grande NM, Somma F. Ultrasonics in endodontics: a review of the literature. J Endod. 2007;33(2):81-95.

25. Al Jadaa A, Paqué F, Attin T, Zehnder M. Necrotic pulp tissue dissolution by passive ultrasonic irrigation in simulated accessory canals: impact of canal location and angulation. Int Endod J. 2009;42(1):59-65.

26. Hockett JL, Dommisch JK, Johnson JD, Cohenca N. Antimicrobial efficacy of two irrigation techniques in tapered and nontapered canal preparations: an in vitro study. J Endod. 2008;34(11):1374-7.

27. Arias A, de la Macorra JC, Hidalgo J, Azabal M. Predictive models of pain following root canal treatment: a prospective clinical study. Int Endod J. 2013;46(8):784-93.

28. Glennon J, Ng YL, Setchell D, Gulabivala K. Prevalence of and factors affecting postpreparation pain in patients undergoing two visit root canal treatment. Int Endod J. 2004;37(1):29-37.

29. Peters OA, Koka RS. Preparation of coronal and radicular spaces. Dugoni School of Dentistry Faculty Books and Book Chapters. 2009;6(27):877-991.

30. Elhafez EA, Soliman AH. Evaluation of Postoperative Pain after Irrigation Using End Vented NaviTip Tips Versus Side 
Vented NaviTip Tips in Teeth with Irreversible Pulpitis: A Randomized Clinical Trial. AADJ. 2018;1(1):79-84.

31. Van der Sluis L, Gambarini G, Wu M, Wesselink P. The influence of volume, type of irrigant and flushing method on removing artificially placed dentine debris from the apical root canal during passive ultrasonic irrigation. Int Endod J. 2006;39(6):472-6.

32. Souza CC, Bueno CE, Kato AS, Limoeiro AG, Fontana CE, Pelegrine RA. Efficacy of passive ultrasonic irrigation, continuous ultrasonic irrigation versus irrigation with reciprocating activation device in penetration into main and simulated lateral canals. J conserv dent . 2019;22(2):155-59.

33. Bago Jurič I, Plečko V, Anić I. Antimicrobial efficacy of Er, Cr: YSGG laser-activated irrigation compared with passive ultrasonic irrigation and RinsEndo® against intracanal Enterococcus faecalis. Photomed laser surg. 2014;32(11):600-5.

34. Siu C, Baumgartner JC. Comparison of the debridement efficacy of the EndoVac irrigation system and conventional needle root canal irrigation in vivo. J Endod. 2010;36(11):1782-5.

35. Mitchell RP, Yang S-E, Baumgartner JC. Comparison of apical extrusion of $\mathrm{NaOCl}$ using the EndoVac or needle irrigation of root canals. J Endod. 2010;36(2):338-41.

36. Gambarini G, Testarelli L, De Luca M, Milana V, Plotino G, Grande NM, et al. The influence of three different instrumentation techniques on the incidence of postoperative pain after endodontic treatment. Ann stomatol. 2013;4(1):152-55.

37. Keskin C, Özdemir Ö, Uzun İ, Güler B. Effect of intracanal cryotherapy on pain after single-visit root canal treatment. Aust Endod J. 2017;43(2):83-8.

38. Gündoğar M, Sezgin GP, Kaplan SS, Özyürek H, Uslu G, Özyürek T. Postoperative pain after different irrigation activation techniques: a randomized, clinical trial. Odontology. 2020:1-8.

39. Pak JG, White SN. Pain prevalence and severity before, during, and after root canal treatment: a systematic review. J Endod. 2011;37(4):429-38.

40. Junior JAC, Coelho MS, Kato AS, Vivacqua-Gomes N, Fontana CE, Rocha DGP, et al. The effect of foraminal enlargement of necrotic teeth with the reciproc system on postoperative pain: a prospective and randomized clinical trial. J Endod. 2016;42(1):8-11.
41. Al-Nahlawi T, Hatab TA, Alrazak MA, Al-Abdullah A. Effect of Intracanal Cryotherapy and Negative Irrigation Technique on Postendodontic Pain. JCDP. 2016; 17(12):990-6.

42. Susila A, Minu J. Activated Irrigation vs. Conventional non-activated Irrigation in Endodontics-A Systematic Review. Eur Endod J. 2019;4(3):96-110.

43. Yost RA, Bergeron BE, Kirkpatrick TC, Roberts MD, Roberts HW, Himel VT, et al. Evaluation of 4 different irrigating systems for apical extrusion of sodium hypochlorite. J Endod. 2015;41(9):1530-4.

44. Akçay A, Gorduysus M, Rahman B, Gorduysus MO. Effects of Six Different Irrigation Systems on Potential Apical Extrusion of Irrigants. J Int Dent Medical Res. 2019;12(1):1-5.

45. Azim AA, Aksel H, Jefferson MM, Huang GT-J. Comparison of sodium hypochlorite extrusion by five irrigation systems using an artificial root socket model and a quantitative chemical method. Clin oral investig. 2018; 22(2):1055-61.

46. Desai P, Himel V. Comparative safety of various intracanal irrigation systems. J Endod. 2009;35(4):545-9.

47. Romualdo PC, de Oliveira KMH, Nemezio MA, Küchler EC, Silva RAB, Nelson Filho P, et al. Does apical negative pressure prevent the apical extrusion of debris and irrigant compared with conventional irrigation? A systematic review and metaanalysis. Aust Endod J. 2017;43(3):129-37.

48. Curtis TO, Sedgley CM. Comparison of a continuous ultrasonic irrigation device and conventional needle irrigation in the removal of root canal debris. J Endod. 2012;38(9):1261-4.

49. Adcock JM, Sidow SJ, Looney SW, Liu Y, McNally K, Lindsey K, et al. Histologic evaluation of canal and isthmus debridement efficacies of two different irrigant delivery techniques in a closed system. J Endod. 2011;37(4):544-8.

50. Shetty VP, Naik BD, Pachlag AK, Yeli MM. Comparative evaluation of the amount of debris extruded apically using conventional syringe, passive ultrasonic irrigation and EndoIrrigator Plus system: An in vitro study. J conserv dent. 2017;20(6):411-14.

51. Tambe VH, Nagmode PS, Vishwas JR, KP S, Angadi P, Ali FM. Evaluation of the amount of debris extruded apically by using conv-entional syringe, endovac and ultrasonic irrigation technique: An in vitro study. $\mathrm{J}$ int oral health. 2013;5(3):63-66. 
52. Tang Z, Wang H, Jiang S. Clinical study of single-visit root canal treatment with a nickel-titanium $(\mathrm{Ni}-\mathrm{Ti})$ rotary instrument combined with different ultrasonic irrigation solutions for elderly patients with chronic apical periodontitis. Biomed Mater Eng. 2015;26(s1):311-8.

53. Rodríguez-Figueroa C, McClanahan SB, Bowles WR. Spectrophotometric determination of irrigant extrusion using passive ultrasonic irrigation, EndoActivator, or syringe irrigation. J Endod. 2014;40(10):1622-6.

54. Karatas E, Ozsu D, Arslan H, Erdogan A. Comparison of the effect of nonactivated self adjusting file system, Vibringe, EndoVac, ultrasonic and needle irrigation on apical extrusion of debris. Int Endod J. 2015;48(4):317-22.

55. Gupta J, Nikhil V, Jha P. Corelation between machines assisted endodontic irrigant agitation and apical extrusion of debris and irrigant: a laboratory study. Sci World J. 2014; 2014(1):1-6.

56. Hizarci U, Koçak S, Sağlam BC, Koçak MM. Effect of different irrigation activation techniques on the amount of apical debris extrusion. Tanta Dent J. 2019;16(1):29-32. 